\title{
THE ASSESSMENT OF TIME MANAGEMENT SKILLS IN CHINESE AND CROATIAN STUDENTS
}

\author{
Kristina Črnjar \\ PhD, Associate Professor, University of Rijeka, Faculty of Tourism and Hospitality Management, Primorska \\ 42, p.p. 97, 51410 Opatija, Croatia; e-mail:kcrnjar@fthm.hr \\ Vedrana Čikeš \\ MA in Economics, Teaching Assistant,University of Rijeka, Faculty of Tourism and Hospitality Management, \\ Primorska 42, p.p. 97, 51410 Opatija, Croatia; e-mail: vedrana.cikes@fthm.hr
}

\section{Kristina Ferenčak}

BSc in Economics; e-mail: k-575@hotmail.com

\begin{abstract}
Time management is the ability of consciously deciding and controlling the amount of time spent on different activities in order to be more productive and effective. In order to achieve academic success, students should be able to manage a large number of activities, from going to lectures, studying, participating in extra-curricular activities, to making sure they are getting enough rest to stay healthy. The purpose of this research was to determine if there are any significant differences in the effective time management between Chinese and Croatian students. Even though the cultural differences between these two groups are substantial, both groups are becoming a part of the same education and business market. The research was conducted on the sample of 340 Chinese and Croatian students using an online survey. The results have shown that in several time management activities there are statistically significant differences between Chinese and Croatian students. The results also indicate that the Croatian respondents are better at setting goals, determining priorities and performing tasks by priority, while Chinese students delegate tasks and determine and eliminate time wasting activities more often than their Croatian counterparts do. On the other hand, Croatian students waste more time on activities such as conducting tasks of small importance and fun activities of no relevance (e.g. "surfing" the Internet, private telephone conversations, chatting, etc.), while Chinese students are in the forefront with regard to ineffective and supernumerary meetings and overly long and supernumerary phone conversations.
\end{abstract}

Key words: time management, time management activities, time wasting activities, students, China, Croatia 


\section{INTRODUCTION}

Over the last 70 years, interest in time management has been growing continuously, together with the importance of time dimensions. Some of the reasons for that are the growth in global competition and immediate demands of service and services (Orlikowski, Yates, 2002). It was once considered that only managers need time management skills, but today it is clear that those skills are necessary for everyone, including students.

Students represent a group in transition between schooling and the business world and require education and assistance in developing their time management skills. Student life is full of often overlapping deadlines and, without proper time planning, students may find it almost impossible to fulfill all of their obligations. Time management skills are important contributors to study success (Macan et al., 1990). Britton and Tesser (1991) reported that time-management practices might influence college achievement. According to Meng and Heijke (2005), students' time allocation skills are related to the acquisition of discipline-specific and generic competencies. Efficient time management is, therefore, crucial to students, not only with regard to their academic success, but also with regard to developing the competences they will need for their future jobs.

This paper aims to investigate the differences in time management behaviors between Croatian and Chinese students. Croatia is a country with just over 4 million inhabitants, while China numbers around 1.37 billion people. Unlike Croatian students, Chinese students live in a country that is not only the most prosperous but also one of the most economically and industrially developed in the world. In addition to the huge differences in the development of the two countries, the cultures of the respondents vary greatly as well. Nevertheless, both of these student groups will become part of the world market in a few years from now and may someday compete for the same job. Therefore, it is important to see whether, in their current student life, there are any differences in their "preparation" for that possibility.

Accordingly, the following hypotheses have been set:

$\mathrm{H} 1$ : There are significant differences in time management activities between Croatian and Chinese students.

$\mathrm{H} 2$ : There are significant differences in time wasting activities ("thieves of time") between Croatian and Chinese students.

The next section gives an overview of the existing literature on time management in general as well as within different groups of people and/or different cultures. Section 3 explains the methodology used in this research, while the main results of the study have been summarized in Section 4. Finally, the conclusions of the study and limitations of this research are presented in Section 5.

\section{LITERATURE REVIEW}

According to Lakein and Leake (1973), time management involves the process of determining needs, setting goals to achieve the needs, and prioritizing and planning tasks required to achieve the goals. It is also generally defined in terms of clusters of behavior that are deemed to facilitate 
productivity and alleviate stress (Lay, Schouwenburg, 1993). Time management can also be observed as a way of monitoring and controlling time (Eilam, Aharon, 2003).

With regard to time management antecedents and consequences, studies have found that a person's personality and time management training affect their time management behavior the most and that time management behavior has positive effects on proximal outcomes, performance, and stress-related outcomes (Claessens et al., 2007).

Differences in time management behaviors have been researched within different groups of people, such as managers (e.g. Pološki Vokić, Mrđenović, 2008), employees in general (e.g. Adams, Jex, 1999; Green, Skinner, 2005), teachers (e.g. Peeters and Rutte, 2005; Woolfolk and Woolfolk, 1986) and students (e.g. Bond, Feather, 1988). Pološki Vokić and Mrđenović (2008) conducted a study exploring the differences in the time management activities of Croatian managers with regard to their gender and hierarchical level. The results of the research show that Croatian managers, on average, manage their time well and that there are no major differences in time management between genders. With regard to hierarchal level, medium-level managers are the most successful and managers at the lowest level, the least successful when it comes to time management. Among a group of university students, Bond and Feather (1988) reported that time structure (total TSQ score) was positively related to the sense of purpose in life, self-esteem, and type A behavior, and negatively to neuroticism and anomie (i.e. the individual's generalized sense of self-to-others alienation).

Few authors have reported on the differences in time management between different nationalities. Rau et al. (2011) conducted a study on the differences in time management between the Chinese, Germans and Japanese. They chose three different cultures that represent different stereotypes: Germans are often described as being very accurate and precise, the Chinese represent a traditional East Asian culture and are often perceived as relaxed in terms of plans and deadlines, while the Japanese culture is an East Asian culture that is known for the efficiency of time usage, especially in the manufacturing industry. The results of the research show that Germans use time management activities more often than do the other two groups, followed by the Japanese and finally the Chinese. The Germans and Japanese also carry out goal setting and prioritizing more often. Chen, Rau and Suriyalaksh (2017) conducted a study about the differences in time management activities in young Chinese and Thai. They used both survey and experiment as a method of data collection. The results of the survey showed that Thai students use more activities related to time management, setting goals and prioritizing. On the other hand, Chinese students prefer organized work and an organized work environment and have better time control. However, the results of the experiments showed that Chinese participants work significantly more on goal setting and task execution.

Considering the different cultural backgrounds of Croatian and Chinese students in this paper, it is also important to mention the study conducted by Sit (2013) on the prejudices the Western world has about Chinese learning styles. In his paper, the author analyzed three major prejudices regarding Chinese students and the characteristics of their learning: rote learning (learning and 
memorizing something based on repetition) that does not contribute to future problem resolving; "silent learning", the silence and obedience of Chinese students in lectures; and passive learning.

The above-mentioned studies investigated time management skills/activities within a particular group of people and within one or more cultures. None of the studies focused on students from different countries. Rau et al. (2011) conducted a study comparing Western and Eastern cultures, but the participants were not students. With regard to that, the specific feature of this paper lies in the research of time management between students of different cultural backgrounds and in the fact that both groups will become part of the business world in the near future.

\section{METHODOLOGY}

The study of time management and time wasting activities was carried out in April 2018. The instrument of the research was an online survey. A link to the survey in Croatian was shared via social networks among Croatian students studying at the University of Rijeka and University of Zagreb. The same survey was translated into English and distributed via the WeChat application among Chinese students at Guangzhou College of South China, University of Technology.

The questionnaire used in this research consisted of 22 questions divided into three sections. The first section refers to the frequency of performing/conducting time management skills/activities (ten questions). Items relating to spending time on activities that are considered to be time wasting (eight questions) belong to the second section, while the last four items are socio-demographic and are part of the third section. Items relating to time management and time wasting activities were taken from Pološki Vokić and Mrdenović (2008). Respondents were asked to declare how often they: $a$ ) perform/conduct time management activities and $b$ ) waste time on certain activities that do not contribute to successful time management. All 18 items were evaluated on a 5-point Likert scale ranging from $1=$ never to $5=$ always, i.e. $1=$ never to $5=$ very often.

The data were processed and analyzed using SPSS v23.

\section{RESULTS}

Results of the analyses, both sample analysis and hypothesis testing, are shown in the following subsections.

\section{1 Sample}

The demographic profile of the respondents is shown in Table 1. 
Table 1. Demographic profile of respondents

\begin{tabular}{|c|c|c|c|c|c|}
\hline & & \multicolumn{4}{|c|}{ Nationality } \\
\hline & & \multicolumn{2}{|c|}{ Chinese } & \multicolumn{2}{|c|}{ Croatian } \\
\hline & & $\mathrm{N}$ & $\%$ & $\mathrm{~N}$ & $\%$ \\
\hline \multirow[t]{2}{*}{ Sex } & female & 123 & 72.4 & 120 & 70.6 \\
\hline & male & 47 & 27.6 & 50 & 29.4 \\
\hline \multirow[t]{5}{*}{ Age } & under 18 & 5 & 2.9 & 2 & 1.2 \\
\hline & $18-20$ & 41 & 24.1 & 16 & 9.4 \\
\hline & $21-22$ & 102 & 60.0 & 61 & 35.9 \\
\hline & $23-24$ & 19 & 11.2 & 53 & 31.2 \\
\hline & over 24 & 3 & 1.8 & 38 & 22.4 \\
\hline \multirow[t]{3}{*}{ Level of study } & undergraduate study & 104 & 61.2 & 106 & 62.4 \\
\hline & graduate study & 62 & 36.5 & 58 & 34.1 \\
\hline & doctoral study & 4 & 2.4 & 6 & 3.5 \\
\hline \multirow[t]{4}{*}{ Average academic success } & sufficient & 38 & 22.4 & 7 & 4.1 \\
\hline & good & 99 & 58.2 & 58 & 34.1 \\
\hline & very good & 23 & 13.5 & 77 & 45.3 \\
\hline & excellent & 10 & 5.9 & 28 & 16.5 \\
\hline
\end{tabular}

In total, 340 students filled out the questionnaire ( 170 Chinese and 170 Croatian students). In both groups, most of the respondents were female, accounting for $72.4 \%$ and $70.6 \%$ of the Chinese and Croatian groups, respectively, while male represented $27.6 \%$ and $29.4 \%$ of the samples. The age of most of the respondents was between 21 and 22 years (60.0\% among Chinese students and 35.9\% in the group of (roatian students). Regarding their level of study, $61.2 \%$ of the Chinese respondents and $62.4 \%$ of Croatian respondents are students at the undergraduate level, while only a few are doctoral students (2.4\% of Chinese and $3.5 \%$ of Croatian respondents). An analysis of the students' average success in college shows that $80.6 \%$ of Chinese respondents have sufficient or good grades, while most of the Croatian students, on the other hand, belong to the groups of good or very good academic success (79.4\%).

The average scores for each of the 10 time management activities were also analyzed. The results are shown in the following chart. 
Chart 1. Time management activities in Chinese and Croatian students

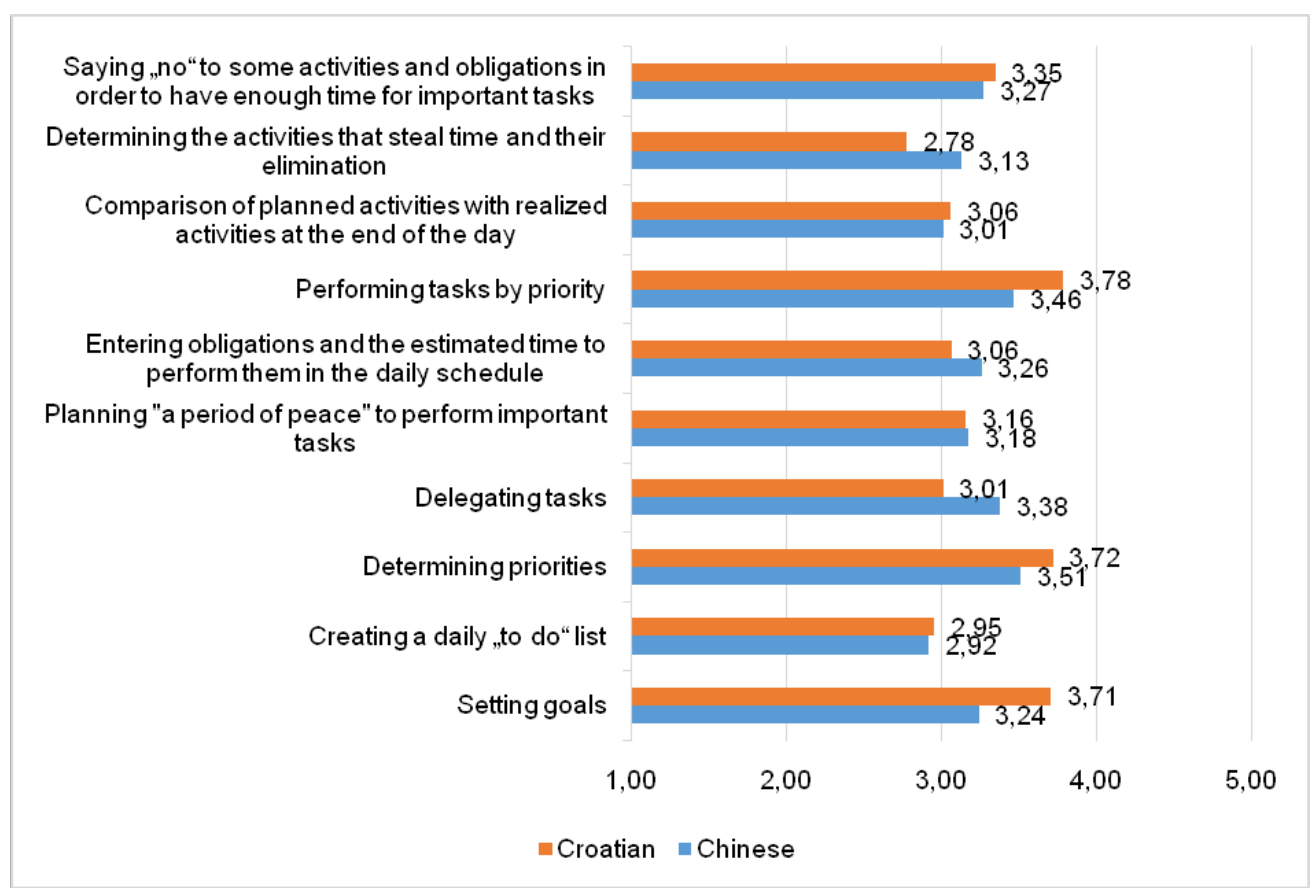

Source: Authors

Based on this chart, it is evident that both groups manage their time very well, especially when considering the scale from 1 to 5 , where 3 means sometimes; 4 , often; and 5 , always. The total average scores of 3.24 for Chinese students and 3.26 for Croatian students show that their satisfaction with managing their time is above average. Out of 10 time management activities, Chinese students perform the activity of determining priorities the most (3.51), followed by performing tasks by priority (3.46) and delegating tasks (3.38). Croatian students find themselves best in performing tasks by priority (3.78), determining priorities (3.72) and setting goals (3.71). "Creating a daily "to do" list" (2.92) and "Comparison of planned activities with realized activities at the end of the day" (3.01) are activities that Chinese students conduct the least as a method of time management. "Determining the activities that steal time and their elimination" (2.78) and "Creating a daily "to do" list" are the methods the least used by Croatian students.

The following chart presents the activities that waste time in both the Chinese and Croatian group of students. 
Chart 2. Time wasting activities in Chinese and Croatian students

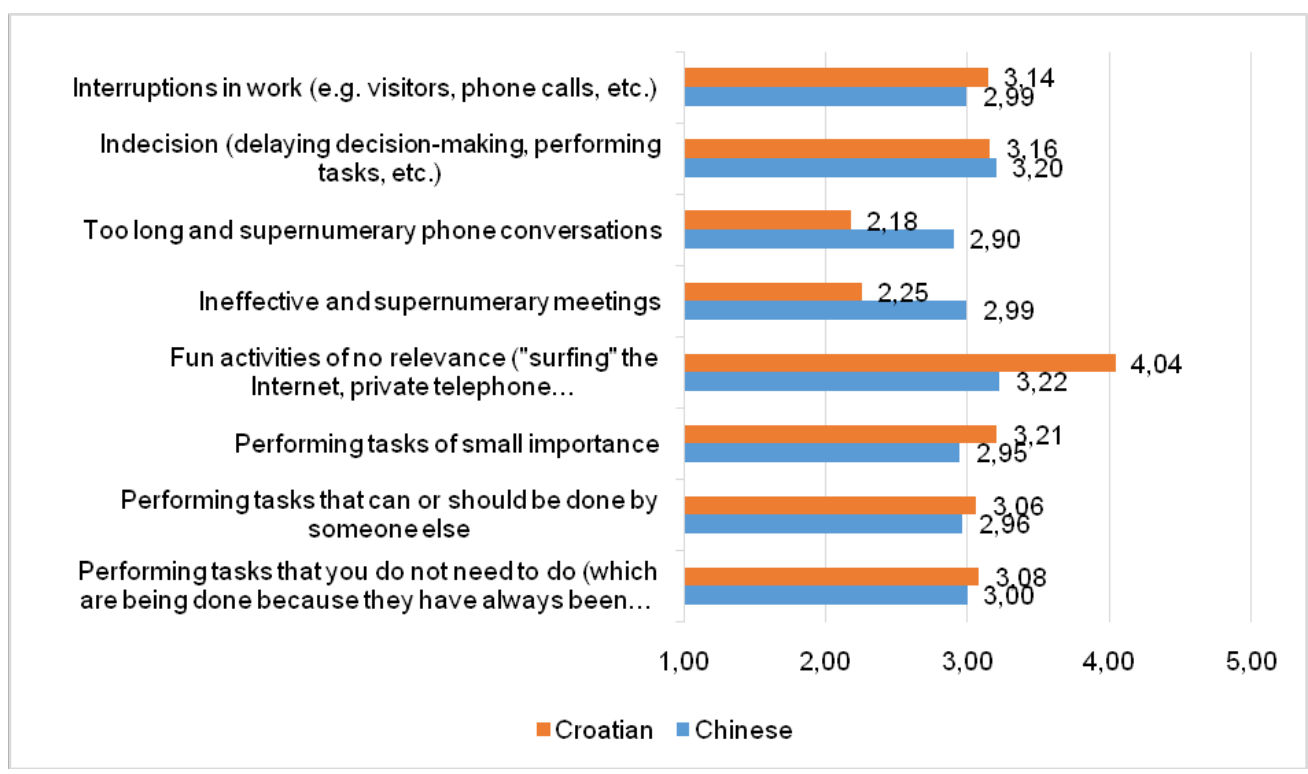

Source: Authors

An analysis of this chart shows that the average scores for time wasting activities are similar, 3.03 for Chinese and 3.01 for Croatian students. Both Chinese and Croatian students waste their time the most on fun activities of no relevance ("surfing" the Internet, private telephone conversations, chatting, etc.). Among the Chinese respondents, only three time wasting activities have average scores higher than 3.0, while in the Croatian group the average scores of five out of eight activities are over 3.0. These results might indicate that Croatian students manage their time more poorly than Chinese students.

\section{2 Hypothesis testing}

Before choosing the appropriate method for testing the hypotheses, all data were tested for normality of the distribution. Shapiro-Wilk and Kolmogorov-Smirnov tests showed that the distribution was non-normal and, for that reason, nonparametric statistics was used. In order to compare differences between the two groups of students (Chinese and Croatian) on the dependent variable (time management activities ( $\mathrm{H} 1)$ and time wasting activities $(\mathrm{H} 2)$ ), the MannWhitney $\mathrm{U}$ test was used for further analysis. The results of the test regarding $\mathrm{H} 1$ are shown in the following tables. 
K. Črnjar, V. Čikeš, K. Ferenčak: The Assessment of Time Management Skills in Chinese...

Zbornik Veleučilišta u Rijeci, Vol. 7 (2019), No. 1, pp. 83-94

Table 2. Differences in time management activities between nationalities (tests)

\begin{tabular}{|l|c|c|c|c|}
\hline & $\begin{array}{c}\text { Mann- } \\
\text { Whitney U }\end{array}$ & Wilcoxon W & Z & $\begin{array}{c}\text { Exact Sig. } \\
\text { (2-tailed) }\end{array}$ \\
\hline Setting goals & 10407.500 & 24942.500 & -4.696 & .000 \\
\hline Creating a daily „to do“ list & 14156.000 & 28691.000 & -.334 & .739 \\
\hline Determining priorities & 12549.500 & 27084.500 & -2.185 & .029 \\
\hline Delegating tasks & 12224.500 & 26759.500 & -2.573 & .010 \\
\hline $\begin{array}{l}\text { Planning "a period of peace” to perform important } \\
\text { tasks }\end{array}$ & 14117.500 & 28652.500 & -.377 & .707 \\
\hline $\begin{array}{l}\text { Entering obligations and the estimated time to } \\
\text { perform them in the daily schedule }\end{array}$ & 13457.000 & 27992.000 & -1.129 & .259 \\
\hline Performing tasks by priority & 11578.500 & 26113.500 & -3.299 & .001 \\
\hline $\begin{array}{l}\text { Comparison of planned activities with realized } \\
\text { activities at the end of the day }\end{array}$ & 14026.000 & 28561.000 & -.480 & .631 \\
\hline $\begin{array}{l}\text { Determining the activities that steal time and their } \\
\text { elimination }\end{array}$ & 12063.500 & 26598.500 & -2.726 & .006 \\
\hline $\begin{array}{l}\text { Saying „,no" to some activities and obligations in order } \\
\text { to have enough time for important tasks }\end{array}$ & 13530.500 & 28065.500 & -1.060 & .290 \\
\hline
\end{tabular}

a. Grouping Variable: Nationality

Source: Authors

Table 3. Differences in time management activities between nationalities (ranks)

\begin{tabular}{|c|c|c|c|c|}
\hline \multicolumn{2}{|l|}{ Nationality } & $\mathrm{N}$ & Mean Rank & Sum of Ranks \\
\hline \multirow{3}{*}{ Setting goals } & Chinese & 170 & 146.72 & 24942.50 \\
\hline & Croatian & 170 & 194.28 & 33027.50 \\
\hline & Total & 340 & & \\
\hline \multirow{3}{*}{ Determining priorities } & Chinese & 170 & 159.32 & 27084.50 \\
\hline & Croatian & 170 & 181.68 & 30885.50 \\
\hline & Total & 340 & & \\
\hline \multirow{3}{*}{ Delegating tasks } & Chinese & 170 & 183.59 & 31210.50 \\
\hline & Croatian & 170 & 157.41 & 26759.50 \\
\hline & Total & 340 & & \\
\hline \multirow{3}{*}{ Performing tasks by priority } & Chinese & 170 & 153.61 & 26113.50 \\
\hline & Croatian & 170 & 187.39 & 31856.50 \\
\hline & Total & 340 & & \\
\hline \multirow{3}{*}{$\begin{array}{l}\text { Determining the activities that steal time and } \\
\text { their elimination }\end{array}$} & Chinese & 170 & 184.54 & 31371.50 \\
\hline & Croatian & 170 & 156.46 & 26598.50 \\
\hline & Total & 340 & & \\
\hline
\end{tabular}

Source: Authors 
The Mann-Whitney $U$ test showed there are statistically significant differences between Chinese and Croatian students in the following time management activities: setting goals $(p=, 000)$, determining priorities $(, 029)$, delegating tasks $(, 010)$, performing tasks by priority $(, 001)$ and determining the activities that steal time and their elimination $(, 006)$. Since the differences were significant for five out of ten tested activities, $\mathrm{H} 1$ was partially supported.

In addition, mean ranks suggest there could be other differences between these two groups: Croatian students more often perform activities of setting goals, determining priorities and performing tasks by priority, while Chinese students are better at delegating tasks and determining and eliminating time wasting activities. This also might indicate that Croatian students manage their time a bit better than Chinese students do.

When it comes to time wasting activities, the results of the performed analyses are shown in the following tables.

Table 4. Differences in time wasting activities between nationalities (tests)

\begin{tabular}{|l|c|c|c|c|}
\hline & $\begin{array}{c}\text { Mann- } \\
\text { Whitney U }\end{array}$ & $\begin{array}{c}\text { Wilcoxon } \\
\text { W }\end{array}$ & Z & $\begin{array}{c}\text { Exact Sig. } \\
\text { (2-tailed) }\end{array}$ \\
\hline $\begin{array}{l}\text { Performing tasks that you do not need to } \\
\text { do (which are being done because they have } \\
\text { always been done) }\end{array}$ & 13846.500 & 28381.500 & -.715 & .476 \\
\hline $\begin{array}{l}\text { Performing tasks that can or should be done by } \\
\text { someone else }\end{array}$ & 13835.000 & 28370.000 & -.715 & .476 \\
\hline Performing tasks of small importance & 12444.000 & 26979.000 & -2.330 & .020 \\
\hline $\begin{array}{l}\text { Fun activities of no relevance (e.g. "surfing" } \\
\text { the Internet, private telephone conversations, } \\
\text { chatting, etc.) }\end{array}$ & 8214.500 & 22749.500 & -7.121 & .000 \\
\hline Ineffective and supernumerary meetings & 8531.500 & 23066.500 & -6.787 & .000 \\
\hline $\begin{array}{l}\text { Too long and supernumerary phone } \\
\text { conversations }\end{array}$ & 9099.500 & 23634.500 & -6.082 & .000 \\
\hline $\begin{array}{l}\text { Indecision (delaying decision-making, } \\
\text { performing tasks, etc.) }\end{array}$ & 14165.000 & 28700.000 & -.325 & .746 \\
\hline $\begin{array}{l}\text { Interruptions in work (e.g. visitors, phone calls, } \\
\text { etc.) }\end{array}$ & 13179.500 & 27714.500 & -1.465 & .142 \\
\hline
\end{tabular}

a. Grouping Variable: Nationality 
K. Črnjar, V. Čikeš, K. Ferenčak: The Assessment of Time Management Skills in Chinese...

Zbornik Veleučilišta u Rijeci, Vol. 7 (2019), No. 1, pp. 83-94

Table 5. Differences in time wasting activities between nationalities (ranks)

\begin{tabular}{|l|l|r|r|c|}
\hline \multirow{2}{*}{ Nationality } & $N$ & $\begin{array}{c}\text { Mean } \\
\text { Rank }\end{array}$ & $\begin{array}{c}\text { Sum of } \\
\text { Ranks }\end{array}$ \\
\hline \multirow{4}{*}{ Performing tasks of small importance } & Chinese & 170 & 158.70 & 26979.00 \\
\cline { 2 - 5 } & Croatian & 170 & 182.30 & 30991.00 \\
\cline { 2 - 5 } & Total & 340 & & \\
\hline \multirow{2}{*}{$\begin{array}{l}\text { Fun activities of no relevance ("surfing" the } \\
\text { Internet, private telephone conversations, } \\
\text { chatting, etc.) }\end{array}$} & Chinese & 170 & 133.82 & 22749.50 \\
\cline { 2 - 6 } & Croatian & 170 & 207.18 & 35220.50 \\
\cline { 2 - 6 } & Total & 340 & & \\
\hline \multirow{3}{*}{$\begin{array}{l}\text { Ineffective and supernumerary meetings } \\
\text { Too long and supernumerary phone }\end{array}$} & Chinese & 170 & 205.31 & 34903.50 \\
\cline { 2 - 6 } & Croatian & 170 & 135.69 & 23066.50 \\
\cline { 2 - 6 } & Total & 340 & & \\
\hline \multirow{2}{*}{\begin{tabular}{l} 
conversations \\
\cline { 2 - 6 }
\end{tabular}} & Chinese & 170 & 201.97 & 34335.50 \\
\cline { 2 - 6 } & Croatian & 170 & 139.03 & 23634.50 \\
\cline { 2 - 6 } & Total & 340 & & \\
\hline
\end{tabular}

Source: Authors

The results of the Mann-Whitney $U$ test show that significant differences regarding time wasting activities between Chinese and Croatian students were found in performing tasks of small importance (.020), fun activities of no relevance (e.g. "surfing" the Internet, private telephone conversations, chatting, etc.) (.000), ineffective and supernumerary meetings (.000) and too long and supernumerary phone conversations (.000). Out of eight tested activities, differences were found in four and therefore it can be concluded that $\mathrm{H} 2$ is partially supported. Further, mean ranks indicate differences in the following: Croatian students perform tasks of small importance and conduct fun activities of no relevance (e.g. "surfing" the Internet, private telephone conversations, chatting, etc.) more often than their Chinese counterparts do, but Chinese are in the forefront with regards to ineffective and supernumerary meetings and too long and supernumerary phone conversations.

\section{CONCLUSION}

The results of this study have shown there are some differences in time management activities as well as in time wasting activities between the two groups of students, one from China and the other from Croatia. Both hypotheses are partially supported, which means that, even though there are substantial differences between the countries where these groups of students are from, in some aspects both groups manage their time very similarly. Even though the average results show that both groups manage their time very well, there is still room for improvement. 
This study is the first known attempt of comparing two groups of students from different cultures and countries with a big disproportion in development; and finding differences in the groups' time management activities. Nevertheless, this study has some limitations. First, the sample of this research was limited to students at three universities. In addition, the scales used to measure time management activities and time wasting activities among students were previously tested on managers.

Future studies could involve larger samples of college students and research could be expanded to include other countries. Furthermore, it would be interesting to see how academic success affects time management skills and, conversely, if time management can improve student performance. Finally, some other managerial skills could also be researched among the college student population.

\section{REFERENCES}

Adams, G. A., Jex, S. M. (1999) “Relationships between time management, control, work-family conflict, and strain”, Journal of Occupational Health Psychology, 4(1), p. 72 https://doi.org/10.1037//1076-8998.4.1.72

Bond, M. J., Feather, N. T. (1988) "Some correlates of structure and purpose in the use of time", Journal of Personality and Social Psychology, 55(2), p. 321 https://doi.org/10.1037/0022-3514.55.2.321

Britton, B. K., Tesser, A. (1991) "Effects of time-management practices on college grades". Journal of Educational Psychology, 83(3), p. 405 https://doi.org/10.1037/0022-0663.83.3.405

Chen, N., Rau, P. L. P., Suriyalaksh, P. (2017) “How Thai and Chinese Young Adults Manage Time?”, Psychology, 8(05), p. 717 https://doi.org/10.4236/psych.2017.85046

Claessens, B. J. et al. (2007) "A review of the time management literature", Personnel review, 36(2), p. 255-276 https://doi. org/10.1108/00483480710726136

Eilam, B., Aharon, I. (2003) "Students' planning in the process of self-regulated learning", Contemporary Educational Psychology, 28(3), p. 304-334. https://doi.org/10.1016/S0361-476X(02)00042-5

Green, P., Skinner, D. (2005) “Does time management training work? An evaluation”, International Journal of Training and Development, 9(2), p. 124-139 https://doi.org/10.1111/j.1468-2419.2005.00226.x

Lakein, A., Leake, P. (1973) How to get control of your time and your life, New York: New American Library

Lay, C. H., Schouwenburg, H. C. (1993) "Trait Procrastination, Time Management”, Journal of Social Behavior and Personality, 8(4), p. 647-662.

Macan, T. H. et al. (1990) "College students' time management: Correlations with academic performance and stress", Journal of educational psychology, 82(4), p. 760. https://doi.org/10.1037//0022-0663.82.4.760

Meng, C. M., Heijke, J. A. M. (2005) Student time allocation, the learning environment and the acquisition of competencies. Maastricht: Research Centre for Education and the Labour Market, Maastricht University Library

Peeters, M. A., Rutte, C. G. (2005) "Time management behavior as a moderator for the job demand-control interaction", Journal of Occupational Health Psychology, 10(1), p. 64. https://doi.org/10.1037/1076-8998.10.1.64

Pološki Vokić, N., Mrđenović, R. (2008) "Razlike u upravljanju vremenom hrvatskih menadžera s obzirom na spol i hijerarhijsku razinu", Economic research-Ekonomska istraživanja, 21(1), p. 35-47

Rau, P.L.P.etal.(2011) “Different time management behaviors of Germans, Chinese and Japanese”, In Proceedings of the ACM 2011 conference on Computer supported cooperative work, p. 701-704. https://doi.org/10.1145/1958824.1958949

Sit, H. H. W. (2013) "Characteristics of Chinese students' learning styles", International proceedings of Economics Development and Research, 62, p. 36

Woolfolk, A. E., Woolfolk, R. L. (1986) "Time management: An experimental investigation", Journal of School Psychology, 24(3), p. 267-275. https://doi.org/10.1016/0022-4405(86)90059-2 


\title{
PROCJENJIVANJE VJEŠTINA UPRAVLJANJA VREMENOM KINESKIH I HRVATSKIH STUDENATA
}

\author{
Kristina Črnjar
}

Dr. sc., izv. prof., Sveučilište u Rijeci, Fakultet za menadžment u turizmu i ugostiteljstvu, Primorska 42, p.p. 97, 51410 Opatija, Hrvatska; e-mail: kcrnjar@fthm.hr

\section{Vedrana Čikeš}

Mag. oec., asistent, Sveučilište u Rijeci, Fakultet za menadžment u turizmu i ugostiteljstvu, Primorska 42, p.p. 97, 51410 Opatija, Hrvatska; e-mail:vedrana.cikes@fthm.hr

\section{Kristina Ferenčak}

Univ. bacc. oec.; e-mail: k-575@hotmail.com

\section{SAŽETAK}

Upravljanje vremenom sposobnost je svjesnog odlučivanja i kontroliranja količine vremena utrošenog na različite aktiunosti kako bismo bili produktivniji i učinkovitiji. Da bi postigli akademski uspjeh, studenti bi trebali moći upravljati velikim brojem aktivnosti, od odlaska na predavanja, učenja, sudjelovanja u izvannastavnim aktivnostima, do toga da se dovoljno odmaraju kako bi ostali zdravi. Surha ovog istraživanja bila je utvrditi postoje li značajne razlike u efektivnom upravljanja vremenom između kineskih i hrvatskih studenata. lako između ovih dviju skupina postoje znatne kulturne razlike, obje skupine postaju dio istog tržišta obrazovanja i poslovnog tržišta. Istraživanje je provedeno na uzorku od 340 kineskih i hrvatskih studenata uz pomoć online upitnika. Rezultati su pokazali da kod nekoliko aktivnosti upravljanja vremenom postoje statistički značajne razlike između kineskih i hrvatskih studenata. Rezultati također upućuju na to da su hrvatski ispitanici bolji u postavljanju ciljeva, određivanju prioriteta i obavljanju zadataka prema prioritetu, dok kineski studenti češce delegiraju zadatke i određuju i otklanjaju aktivnosti koje kradu njihovo vrijeme nego što to čine njihovi hrvatski kolege. S druge strane, hrvatski studenti troše više vremena na aktivnosti kao što su obavljanje zadataka od male važnosti i zabavnih aktivnosti ni od kakve važnosti ("surfanje" internetom, privatni telefonski razgovori, čavrljanje i sl.), dok kineski studenti prednjače u neefikasnim i prekobrojnim sastancima te predugim i prekobrojnim telefonskim razgovorima.

Ključne riječi: upravljanje vremenom, aktivnosti upravljanja vremenom, aktivnosti gubljenja vremena, studenti, Kina, Hrvatska 